\title{
Chapter V \\ Conclusion - The Past Is Always Tense, the Future Perfect
}

To survive,

Know the past.

Let it touch you.

Then let

The past

Go.

Octavia Butler

"Now More Than Ever," a short story by Zadie Smith that was published in The New Yorker in 2018, is an off-center, surrealist satire about academia, paranoia, popular and call-out-culture. It also features some of Smith's favorite themes: beauty, postmodern temporality, Black history, and old-fashioned Hollywood movies. All are explored simultaneously when the narrator, an unnamed, elderly, (maybe) female philosophy professor, visits a screening of A Place in the Sun from 1952, whispering improvised dialogues for the mostly silent, servile Black character in her companion's ear: "Yes, Miss, I'll bring the dessert out now. I mean, my brother was lynched not long ago, down in Arkansas, but I can see you've got bigger fish to fry - I'll get right on it." Framing the narrative is the impending scandal and expulsion of a colleague, a character that the professor secretly identifies with but denounces like the rest of the department:

How Eastman still has a job we really don't know. Not only does he not believe the past is the present, but he has gone further and argued that the present, in the future, will be just as crazy-looking to us, in the present, as the past is, presently, to us, right now! For Eastman, surely, it’s only a matter of time. (Smith 2018 para. 5)

In the end, that character blurs into that of a poet endorsed by the department who had "said that philosophy makes nothing happen and also that he happened to quite like the Devil" - most likely a reference to Kanye West's endorsing of Donald Trump (Smith is an avowed fan) - and as he is soon "cancelled," so is the story's first-person narrator. At one point, the ageing professor engages in an email exchange with a high school student, discussing the merits of subtlety or explicitness of metaphor, based on a recent article published in Philosophy Today but exemplified with a clear reference to Childish Gambino's This Is America:

Ә OpenAccess. (c) 2021 Dominique Haensell, published by De Gruyter. (cc) BY-NC-ND This work is licensed under the Creative Commons Attribution-NonCommercial-NoDerivatives 4.0 International License. https://doi.org/10.1515/9783110722093-006 
Dear High-School Student,

Have you seen that video? It's a little like that. Some things are so obvious that subtle metaphor is impossible. In that video, for example, there was no point in being subtle about the state-funded violence inflicted on black people in this country: the only way was to show it explicitly. And when we saw all those people dancing in the foreground that was again the most obvious metaphor possible - i.e., while you're watching these black people dance and entertain you, other black people are dying. (para. 14)

Throughout the exchange, the professor tries to maintain dignified authority but in reality is not so sure about the aesthetic sublimation of suffering. When the professor dubs the mute servant in A Place in the Sun, it is done for grimly comic relief, yet in the full knowledge that

nothing I could do in the present could ameliorate or change this fictional fact; no, all I could do was remember it, and tell myself I was remembering it - so that it wasn't forgotten, although with the mental proviso that suffering has no purpose in reality. To the suffering person suffering is solely suffering. It is only for others, as a symbol, that suffering takes on any meaning or purpose. No one ever got lynched and thought, Well, at least this will lead inexorably to the civil-rights movement. They just shook, suffered, screamed, and died. Pain is the least symbolic thing there is. (para. 10)

Besides its social commentary, Smith's short story may be a self-knowing allusion to her own work, particularly her 2016 novel Swing Time. Here, Smith is equally interested in exploring the complex node of temporality, race, and history and also guilty of trading in fairly obvious metaphors. While the uneven distribution of time or futurity along the gradients of class and race is symbolized by the recurrent image of watches - one an ostentatiously large Swatch wall clock decorating a middle class home and drawing the envy of the protagonist, the other a defunct wristwatch on the arm of an abject poor in an unnamed African country - the history in and as race is also explored through racial tropes of cinematic history and a reference to the West African Sankofa myth, told by the narrator's fervently activist mother: "It's a bird, it looks back over itself, like this.' She bent her beautiful head round as far as it could go. 'From Africa. It looks backwards, at the past, and it learns from what's gone before. Some people never learn"” (Swing Time 30).

The concept of Sankofa, quite widely known in diasporic contexts, transports a specific Afro-diasporic notion of temporality. Linking to, yet also distinguishing, the Sankofa concept from Benjamin's Angel of History and his focus on a past appropriated by Jetztzeit, the time of the now, Susan Arndt writes ${ }^{103}$ :

103 The article seeks to develop the notion of "FutureS" as an analytical category through 
Reading the beak as the symbol of both communication and nourishment, the picking backward represents an active decision-making about which memories (as narrations about the past) to choose [...]. Whereas the Angel of History and Benjamin's interpretation thereof feature the power that the past holds over the present with hardly any concern about access to futureS, here, the present holds power over the past being selective on behalf of dream^hoped futureS. Thus, rather than Benjamin's continuing the past and its present, the bird's bridging of the past, present and futures is all about agency, which gives space to discontinuity even in the heart of continuities. (2017: 10)

Metahistory as the conscious process of glancing backward may signal an equally ambiguous object for Smith, who has quipped that "the past is always tense, the future perfect." 104 For one, she harbors no romantic notions of a past not designed for her. In an acceptance speech published as "On Optimism and Despair” in her essay collection Feel Free, Smith expounds:

I find these days that a wistful form of time travel has become a persistent political theme, both on the right and on the left. On 10 November The New York Times reported that nearly seven in ten Republicans prefer America as it was in the fifties, a nostalgia of course entirely unavailable to a person like me, for in that period I could not vote, marry my husband, have my children, work in the university I work in, or live in my neighborhood. Time travel is a discretionary art: a pleasure trip for some and a horror story for others. (2018: 37)

Indeed, contemporary public discourse is often characterized by a strange nostalgia, expressed not only in dangerously retrograde politics but also in what Simon Reynolds defines as pop culture's addiction to its own past (2012), or what Zygmunt Bauman, in his posthumous publication Retrotopia (2017), described as contemporary societies' inability to imagine anything but the return to an idealized past. But the very concept of a better past can only be maintained if one conveniently ignores the majority of people on this planet, for whom the

somewhat confusing neologisms: "The capitalized "S" in both FutureS and futureS suggests that 'future' does not exist in the (simplicity of any) singular, and this is largely due to three reasons: First, the ' $S$ ' refers to the fact that futureS are causally intersected with both the past and the present. Second, it draws attention to the fact that futureS are intersected and molded by complexities and coexistences of glocal encounters of conflicting, competing, and complementary agencies, interests, contingencies, possibilities and options in the un/making and (not) sharing of futureS. Consequently, and third, futureS are made (as guided by agencies in power) and can be un*made (through resistance)" (3).

104 In fact, the narrator in Smith's White Teeth actually warns about buying into this "wicked lie" (2001: 541). 
'good old days' were anything but that. ${ }^{105}$ Smith's observation that for "a black woman the expanse of livable history is so much shorter" (2018: 38) probably also fuels historian Olivette Otele's uninterest in time travel. In an interview conducted in March 2018, months before she would become the UK's first (!) Black woman history professor, Otele gave a simple and straightforward answer to a history journal's question which moment in time she would like to go back to: "Now is a good place for me as a scholar and a black woman” (2018: para. 5).

Despite its complications, history, and particularly Black history, remains an important resource for diasporic writers like Smith - or Cole, Adichie, and Gyasi. Consequently, Blackness often becomes something to be learned, studied, or immerse oneself in. For example, when Ifemelu reads "every James Baldwin title on the shelf" (Americanah 135), Sonny constantly rereads The Souls of Black Folk (Homegoing 243), and when Cole, in his essay "Black Body," not only revisits the Swiss town where Baldwin wrote "Stranger in the Village" but actually runs a bath and lies "neck-deep in the water" with his "old paperback copy" of Notes of a Native Son, the sound of Bessie Smith playing on his laptop (2016: 4). Generally, all of these authors insist on the value of reading. This shows in the abundant references to books as material objects, but also in plain descriptions of the power of reading. Contrary to the self-referential play of historiographic metafictions, there is really nothing cynical about this kind of intertextuality, no irony, no hint of self-deprecation or self-adulation, just an earnest, and oftentimes urgent admiration for the mental sanctuary provided by literature.

This reverence of reading does not suggest a certain naiveté concerning the political dimension of literature. On the contrary, books are selected and read with purpose and meaning, even if this occurs unconsciously. Ifemelu, for example, reminds an unsuspecting reader that no one is "miraculously neutral in how [they] read books" (190). Open City often exhibits explorations of Yoruba culture and other subaltern histories, markedly juxtaposed with what Baldwin had described as "these white centuries" - a received Western cultural canon, boldly appropriated rather than harmonically fused (1968: 4). The church scene in Brussels allegorizes this notion of disharmonic and contrapuntal histories, disrupting the complacent self-image of a liberal multiculturalism that renders alternative claims and traumatic histories unpalatable - even when they morph into the aestheticized commodity of jazz. Julius recognizes this, but he is unable to become a vessel, translator, or ambassador for these claims - he is unwilling to em-

105 Unwitting proof of this may be the proliferation of 'colorblind casting' in pop culture, such as Lin-Manuel Miranda's Hamilton (2015) or Shondaland's Netflix series Bridgerton (2020). 
body a bridge. Part of his reluctance springs from this very same recognition: that doing so will be perceived, at best, as self-exoticizing or commercially viable, if not disrupting and petulant.

When Cole in "Black Body" claims that he does not need to surrender the "intimidating beauty of Yoruba-language for, say, Shakespeare" because he is "happy to own all of it," he is explicitly engaged in the kind of Afropolitan world-making that fuels these novels' utopian subtext (2016: 10). There is, he writes, "no world in which" he would do so, embodying the confident poise of the Afropolitan who needn't write back nor employ a victim's narrative to be part of this world. Opposing what Cole describes as Baldwin's "self-abnegation" about what he perceived as both the paragon of art and a heritage that excluded him, could be mapped onto earlier responses to Baldwin that function as subtle diasporic critique of an African American primacy regarding Black experiences (Cole 2016: 11). As Nadia Ellis notes in Territories of the Soul, George Lamming also chastised Baldwin for his feelings of "inferiority, both personal and racial," contrasting Baldwin's tormented attitude toward white Western culture with the "certain leisure" gained from living in a majority Black country (qtd. in Ellis 2015: 74). But Lamming's assertion that "No black West Indian in his own native environment would have this highly oppressive sense of being Negro" not only belies the complexities of colonialism, but, as Ellis notes, also reveals Lamming's own ambiguous positioning as a minority Black writer in majoritywhite exile (ibid.). Likewise, Ifemelu's claim of a racism-free Nigeria is not only interpretable as a utopian antidote to a racism-ridden US but must be refracted through the lens of a writer who knows and claims both experiences and thus challenges hegemony through lateralization. This awareness that the Afropolitan world, to be truly that, does not end at the coastline of Africa, but of course encompasses all, sustains these authors' negotiations and explorations of Blackness, particular those triggered by African American struggles and experiences. As such, the novels actively grapple with these legacies, and, while emphasizing the historicity of Blackness, also inquire into the ways in which race in/as history continues to evolve and adapt, curiously posing as timelessness.

How do you inherit a scar? This question, posed most overtly by Homegoing, also mobilizes the other novels' investigation of unresolved and perhaps unresolvable trauma. After being confronted with Moji's rape accusation, Julius muses: "I had been ever-present in her life, like a stain or a scar" (OC 244). And yet, as Moji concedes, her confrontation alone will not change the course of history: "It only needs to happen once" (245). While this could also be related to the painful histories of the Black Diaspora, structurally unacknowledged despite the evidence, countlessly retold yet not generally felt, one need not even extrapolate so far. Whose memories matter? In a post-\#MeToo age, Moji's conten- 
tion that she is "just another woman whose story of sexual abuse will not be believed" rings eerily familiar (ibid.). Or does it ring familiar precisely because a temporal marker like 'post' will not affect the timelessness of this tale? Somewhat resignedly, Open City suggests that it may not even matter if the subaltern is heard or believed because no response formed by the axioms of today can alter the past and change the course of history. And yet, as Kimberlé Crenshaw asks, what if America had believed Anita Hill? What fateful chain of political developments could have been prevented by this simple act of trust? ${ }^{106}$

Still, there may also be merit in Julius's reticence, his unwillingness or inability to actively respond to someone else's trauma. Already with Moji's revelation, Julius highlights the impulse to convert the scene into an aestheticized spectacle. Traumatic accounts, this suggests, may be all too easily sublimated, packaged and sold as easily consumable testaments of other people's pain, and read as reports of distant tragedies. Deifying the conscience-pricking victim narrative of what Robert Eaglestone describes as "African trauma literature," all the authors discussed here address the conundrum of nevertheless narrating the traumatic repercussions of history. In these novels, abstract notions of trauma and public recognition make way for introspective and personal reckonings and explorations of quotidian experience that forgo the merely didactical or engaged, as well as the grand narrative of counterhistory. Sometimes, this occurs within the novels, as in Ifemelu blogging the The Small Redemptions of Lagos, or via the libidinal dynamic of Homegoing's episodic "love stories." Sometimes, this point is made elsewhere, as in Cole's Twitter series "Small Fates." "On Twitter, too, Cole has provided his own commentary on the usage of this literary form, the fait divers: "The small fates are tragicomic at a distance. Closer to home they are of necessity more tragic. There's a tension between the two." It is this tension, the interplay between an earnest dedication to tragic fates and the unwillingness to perform these tragedies as spectacles of fated peoples - that also characterizes these novel's treatment of race in/as history. Dedicated to detailing

106 Crenshaw, who famously developed the concept of intersectionality, was also part of Anita Hill's legal team during the sexual harassment case against Supreme Court Justice nominee Clarence Thomas. In a speech in April 2019, she illuminated the historical continuity and possibly disastrous political repercussion of the Kavanaugh case. She also made a strong case for the value of intersectional practice by pointing to the deep-seated sexism that caused large parts of the African American population to question Hill on account of protecting a respectable "Race Man” like Thomas.

107 Depicting curious snapshots of contemporary life in Nigeria, they read, for example, like this: "With a razor blade, Sikiru, of Ijebu Ode, who was tired of life, separated himself from his male organ. But death eluded him.” 
the normalcy of Black life on both sides of the Atlantic, Cole's "small fates," Adichie's "small redemptions," and Gyasi's "love stories" are not superfluous or adjacent investigations of race in/as history. In many ways, their epistemological stance resembles that of Foucault's petit récits, as the kind of "imperceptible events" which, following Bhabha, encrypt the value of modernity "in signs apparently without meaning and value - empty and eccentric - in events that are outside the "great events of history" (2004: 348).

But the history of race and Blackness, then, is not only something to be read and revisited. It is also something to be written and rewritten. These novels, among many other things, endeavor to make time palpable, for example, when Open City's Julius muses over "time [becoming] material in a strange new way" (219) or Marcus in Homegoing, thinking about how his racialized self intersects with the "accumulation of these times," wants nothing else for his book project than to capture the "feeling of time" (295). Probing the confines of a "race-timecontinuum" (Stallings 2013: 194), they provide an answer to what it feels like to be raced: It's a particular way of being timed, as 'not yet,' as waiting, as accumulation, as embodied history, as memories of tom-toms, as too-late, as offbeat, as fated or fallen out of time. While the revisiting and rewriting of race in/as history has of course been done before, this does not make these accounts any less significant. These things cannot be 'overdone' or overstated. The fact of race is infinitely startling, its histories infinitely troubling, particularly because the confrontation with, and uncovering of, historical violence continues to take place under the sign of this violence. Regardless of the familiarity of the narrative, Hortense Spillers reminds us, "every writing as revision makes the discovery again" (2003: 209).

In probing, navigating, and negotiating Blackness, these authors are consciously inscribing themselves into a tradition that often tends to neglect contemporary African voices. By historicizing Blackness, they avoid the pitfalls of claiming an experience that is not theirs while positioning themselves within an entangled history. As such, they easily identify the "simplistic comparison" behind attempts at pitting the new against the old diaspora (Adichie, Americanah 168). By they also identify it behind the reproach that they're not feeling what they're writing because they're "writing from the outside" (ibid. 336). Countering this, these novels can be read as a call "to understand a bit more history" (ibid. 168). Expanding the narrow frame of Blackness, they are not only able to insert themselves, but also acknowledge their own responsibility and position. The Black Diaspora, then, is the "forest" of Homegoing's epigraph: "if you are inside you see that each tree has its own position." Foregrounding their formal distinctness from the kind of "strict historical record" that stifles Julius's patient V. 
(OC 27), these novels are able to provide a long view of history and contain the melancholy that always threatens to cloud that vision.

In the current political climate, as the noose continues to tighten, those who have no time to mourn a past they never owned and who have nowhere else to go but the future, have, for some, begun to signal the last glimmer of hope. This becomes apparent in the more general idea that Black Americans are the perfecters of democracy. Examples are the New York Time's hugely successful "1619 Project" and the much-evoked notion that Black (women) voters 'saved us' during the crucial elections of 2020 and 2021 - with "Thank Black Voters" op-eds often illustrating the kind of hollow liberal gratitude that barely conceals its solipsism. Yet the recent years have also seen more substantial public interest in the hard-won insights gained by Black thinkers and activists - for example the abolitionist movements pushing for a reevaluation of common safety amidst the relentless militarization of the American public. As George Lipsitz writes in "The Changing Same":

\footnotetext{
New social movements are emerging in this conjuncture. They are often race based but rarely race bound. They recognize racism as a technology of power, as a justification and excuse for unfair gains and unjust enrichments. They see racism as innately intersectional, as ever present, but never present in isolation from sexism, homophobia, imperial conquest and class subordination. These movements acknowledge the long fetch of history, the depressing collective, cumulative and continuing consequences of slavery unwilling to die, yet they also perceive new possibilities for the present and for the future. They challenge the logics of color blindness and balanced budget conservatism by drawing on the enduring and viable repressed radicalisms of previous eras. (2018: 17)
}

Simultaneously, Black America's popular culture has emerged from its so-called "category crisis" with a newfound, defiantly (post-post-) racial aesthetics, exploring the contemporary complexities of race and racism through absolutely stellar cultural productions. Donald Glover's aka Childish Gambino's This Is America is one of them, and so is his FX series Atlanta. This new wave of Black cultural production is also host to a choir of different Black voices, from British-Ugandan actor Daniel Kaluuya, who stars in Jordan Peele's sensational Get Out, to Senegalese-American Issa Rae, who, with the series Insecure and Awkward Black Girl, has created two of the most refreshing representations of contemporary Black America. The visibility of these newly Black Americans, however, does not presuppose a mere subsuming under an African American rubric of Blackness. On the contrary, these processes are often accompanied by the valuation and reevaluation of the "African" signifier that defines the Afropolitan moment. This process has never been limited to a howsoever defined "apolitical" aesthetic but has of course always encompassed both. While many commenta- 
tors rightly observe how African immigrant groups in the US have largely clustered into national and ethnic groups that reject the generalizing term "African," signaling the dynamic of diaspora nationalism, it appears as though "African" this highly synthetic and indeterminate category - is also (re-)emerging as a politics. Simon Gikandi observes: “As African communities encounter racism, they want to develop connections, political movements, solidarity, and one way of unifying them is by invoking that term 'African.' So, in times of crisis African becomes a conceptual category with more force than it has in everyday life" (2016: 44).

This strategic employment of Africanity is not limited to the US. Indeed, as movements like the South African \#RhodesMustFall intersect with similar concerns in Europe and the US, as racist statures topple globally, questions of reparations become concrete again and looted artifacts are beginning to embarrass museums across the Northern hemisphere, “Africa” becomes yet again a political sign around which to coalesce. It is indeed the urgency of African migrations, turning the Mediterranean into an open wound "where the Third World grates against the first and bleeds," that most crassly belies he advent of Black cosmopolitanism but at the same time helps to establish this newly forged and long forgotten web of political solidarity (Anzaldúa 1999: 25). Acknowledging the globality of anti-Blackness, as many scholars and activists have, ${ }^{108}$ means theorizing history as a violent continuity discernible through uncanny echoes, for example, when Christina Sharpe identifies in the precarious vessels drifting on the Mediterranean a continuation of "the semiotics of the slave ship," highlighting not only the entanglement of slavery and contemporary "forced movements of the migrant and the refugee" (2016: 21) but also their larger embeddedness in what she calls the "crisis of capital and the wreckage from the continuation of military and other colonial projects of US/European wealth extraction and immiseration" (ibid. 59).

In many ways, the moment of Afropolitanism gives rise to this rediscovered vocabulary of a shared political imaginary sustained by historical continuities, but just as Sharpe also endeavors to imagine "new ways to live in the afterlife of slavery" (2016: 18), so does the African signifier undergo change and renewal

108 The global nature of anti-Blackness is not only an avowed tenet of Afro-pessimism - what Wilderson calls the "global common denominator" of the "White and non-Black position" (2010: 51) - but is also a prerequisite for \#BlackLivesMatter's international chapters and a key concern of the movement's co-founder, Opal Tometi. It has been theorized widely, for example, in relation to Western immigration laws, as a necessary condition for the expansion of capital, or, more generally, as constitutive to global white supremacy and condition for Western modernity. See Wynter 2003; Bashi 2004; Mills 2014; Gordon 2017; Bledsoe and Wright 2019. 
in what Mbembe calls the Afropolitan "worlds-in-movement” (2005: 28). Sometimes, this shared imaginary might also mean at least temporarily abandoning the abstract plane of theorizing anti-Blackness as principally and immediately operative, and acknowledging that, as Gikandi notes, "there are many parts of the world in which race is quite low on the totem pole of terror and as a cause of social death" (1996: 607). What would it mean, for example, to fuse the historical sensitivity demanded by the case for reparations with the notion of climate debt, as droughts and floods continue to wreak havoc on those regions underdeveloped by Europe? Far from denouncing the validity of Blackness as a socio-political identity or signaling an end to Black diasporic solidarity, realizing how Blackness intersects differently with the time and space of its articulation is a vital tool for disrupting the permanence of race in/as history, countering racial essentialism and building an antiracist future.

However, while these novels do not 'make Black(ness) history' as a form of socio-political organizing, there is a distinct polysemy to the phrase that nevertheless retains a utopian dimension, not unlike Paul Gilroy's position in Postcolonial Melancholia. Hope, here, is intimately tied to notions of conviviality that transcend the intradiasporic communications that are primarily examined in Making Black History. In this distant cosmopolitan vision, the often painful and violent stories of Blackness may indeed be made history. Even as these texts detail the contemporary implications and long-lasting effects of race in/ as history, one should, in the words of Gilroy, perhaps not interpret the "ancient invocation of the color line as a suggestion that 'race' is a fatal, unchanging principle of political cultures that stretches unbroken and infinite into a future that is defined, just as the past was, precisely by the violent force of racial divisions" (2005: 38).

While Cole's "On the Blackness of the Panther" illuminates how "those who have to learn black also expand what black can be," it also resonates the predicament of dreaming beyond the nation state while attending to the complexity of the diaspora, and particularly the African continent. "African countries have always been in conversation with the world," he writes, "[a]n isolationist blackness is incoherent and impossible: we already been cosmopolitan." Against this mutual imbrication of Africa and the world, he reminds us to be "particular about being particular about what we are talking about when we talk about Africa." The novels investigated are constantly giving shape and complexity to whatever "Africa" may signify in the diasporic and global imaginary. How may Afropolitan fictions maintain and develop the utopian 'extranationality' of diasporic writing in the $21^{\text {st }}$ century? As a testing ground for a solidarity built on difference, these novels' literary world-making really functions as an anteroom for Black cosmopolitanism, that is, the building of a world in which Black humanity 
and belonging is given, not merely by proudly proclaiming cosmopolitanism, but also by negating this kind of belonging and thus indicating other and better worlds.

Considering the extraordinary nuance and richness of cultural, intellectual, and political Black discourse, it is perhaps unsurprising that Black culture and thought symbolizes yet again a path through the mired present and into the future. As such, so-called 'diverse' stories and representations are utilized to quicken the dwindling flow of the mainstream, particularly in Hollywood, where remakes and sequels have replaced novel ideas, often substituting innovation with surface level diversity. It is perhaps not surprising that the vocabulary and semiotics of counterculture have become once again sources of rejuvenation. Yet this issue highlights the problems of co-optation or representation versus redistribution as much as the question, posed by Smith's professor in "Now More Than Ever," whether particularly Black suffering has become a mere cypher, a citable index of a perpetually violent history that neither saves and makes whole the suffering of the past nor alters the present. This is a complicated issue, questioning the extent to which the representations of (historical) violence reproduce rather than undo the violence of lived experience, and there is surely no definitive answer. Besides an acknowledgement of the political urgency of these issues and a celebration of heightened visibility, there is also a pronounced push back against the appropriation of this work and the logics of tokenization.

In late 2017, I visited an extensive event series named "The Milieu of the Dead," organized by the Berliner Humboldt Forum, the highly contested institution set to host Prussia's ethnological collection in the nostalgic nightmare that is the reconstructed Berliner Schloss. In what can only be described as a preemptive move, the Humboldt Forum, as a self-described "platform for debate," had invited scholars Saidiya Hartman and Christina Sharpe to investigate the "Afterlife of Slavery and the Gaps of the Archive.” The event, in short, was an awkward, over-produced disaster. Sharpe and Hartman, it turned out, had been flown in as a mere gesture toward, or indeed index of, their work. This signaled the co-optation or incorporation of an uncomfortable critique that literally never left the realm of representation as both theorists were sat on pedestals, asked to read, and then seated in the audience and excluded from the subsequent discussion about the future of the Humboldt Forum. Sat thus, they were forced to witness an agonizing and futile exchange between predominantly white German curators and historians, oscillating between PR damage control and theoretical abstraction. As this was a two-day event, Sharpe and Hartman had picked up on this dynamic on the first night. For Sharpe's reading on the second night, in which she built on the very concrete questions of repair and social justice that Hartman had put forth the night before, they had prepared a response. 
First, Sharpe read from In the Wake, choosing the harrowing account of the "leftto-die-boat," the boat that had left Tripoli with 72 Africans in March 2011 and reached the coast of Libya two weeks later with only 9 left alive. Then, she read out their joint statement:

Last night Saidiya Hartman began with a question: How do we attend to Black Death? A question we must return to again and again, since our suffering to the degree that it is recognized, is exploited in the service of rehabilitating anti-Black and colonial institutions. The vampires continue to feed on us. Our deaths are not the prequel to a discussion about reforming institutions that were and remain instruments of colonial violence. Our work, each and every word we have ever written is a critique of this project and of the world built on stolen land, stolen lives, stolen labor, stolen objects, stolen futures.

Saidiya and I reckon with Black Death, with Black life in the wake with the intent of making possible other ways of living/other ways of inhabiting the earth. Don't use our death, our suffering, our lives and our work to regenerate your projects. Don't turn our flesh into gold again. We do not consent to this.

What does it mean if Black suffering becomes a political cypher? What does it mean if intellectual projects appropriate Black critique to appear fresh, cutting edge, or as if their own ideas had not "run out of steam"? What does it mean when capitalist institutions sell diversity as innovation, if Black people become tokens of futurity? What does it, in fact, mean if Africa is declared the future?

As curator Bonaventure Soh Behjeng Ndikung asked at the 2015 African Futures Festival in Johannesburg, an interdisciplinary international project funded by the German Goethe Institute: "What is this sudden interest in futurism and the future [...], what are we trying to skip in not talking about the present, and not talking about the past?" (131) Instead of overdetermining Africa by a disjunctive past or future, it might be time to thoroughly realize its present. As I have argued in relation to the intradiasporic signification of Afropolitanism, it is problematic to mobilize Afropolitan futurity against an allegedly backward African American historicism - not only because of the attendant cultural politics but also because this perspective fails to recognize Afropolitanism's own historicisms.

At the same time, Afropolitanism is indeed decidedly 'of the moment,' inviting the world to realize what Africa contributes to this 'now,' even, or precisely as it is haunted by the ghostly remnants of obstinate histories. As we begin to be more "particular about being particular about what we are talking about when we talk about Africa," Africa may be awarded the kind of specificity that also translates into normalcy. Simon Gikandi has identified a certain "African Exceptionalism," positive or negative, as one of the main challenges for African writers and intellectuals today: "How do you go about conducting African conversations as ordinary conversations?” Positing the African “as ordinary, as a subject, a nor- 
mal, ordinary human being" must also entail a firm grounding in the present (2016: 58). Surely, the contemporary presence of Africa can only ever be realized in and as the present. As such, one must insist on African modernity as a global modernity in the same way that Gilroy insisted on Black modernity as northern hemispheric modernity.

Contrary to culturalist or nationalist nostalgic projects hoping to resuscitate a romanticized past, Black people and other historically marginalized groups open history's violent chapters first and foremost with the hope of opening up a different, better future. Similar to Ranjana Khanna's notion of a "critical melancholia" that does not serve but undercuts nationalism, so did Stephen Best and Saidiya Hartman once describe their work as being concerned with "the contemporary predicament of freedom, with the melancholy recognition of foreseeable futures still tethered to this past" (2005: 5). Best has since warned of transmuting this historicist perspective into an axiomatic affect. And there are indeed good reasons for abandoning the past "as it falls away, as that which falls away" (Best 2012: 466), and, instead of waiting for the convoluted knots of history to unravel, grasp a hold of the present and realize a future. We will not wait. Now is a good time. 